\title{
THE USE AND ABUSE OF SENTENCE ENHANCEMENT FOR FIREARMS OFFENSES IN CALIFORNIA*
}

\author{
Alan Lizotte $\dagger$ \\ AND \\ MARJORIE S. ZATZ** \\ INTRODUCTION
}

Over at least the past quarter century there has been considerable debate about the "gun problem" in the United States. Proposals up to and including banning bullets and confiscating guns have been suggested. Policies directly and indirectly affecting legitimate gun owners almost always meet stiff opposition. In part, this opposition results from the tenacious and tightly knit "gun culture." Members of this culture are steeped in the folkways and mores of sporting gun use. They bridle at any attempt to blame them for crime or restrict them in what they see as responsible behavior on their part. Similarly, those who own guns for protection want crime levels enormously reduced before they surrender their own guns. Additionally, given the large number of privately owned guns in the United States today, ${ }^{2}$ the technical and legal impediments to effective gun prohibition may be insurmountable.

One policy, however, typically receives support from both pro- and anticontrol forces: Individuals committing crimes with guns should receive harsher punishments than those who do not use firearms. ${ }^{3}$ As Colin Loftin and David McDowall point out:

Copyright (c) 1986 by Law and Contemporary Problems

* The data utilized in this study were collected and made available by the State of California Department of Justice, Bureau of Criminal Statistics. The Department of Justice bears no responsibility for the analysis or interpretations presented here. Requests for reprints should be sent to Alan Lizotte, School of Criminal Justice, State University of New York at Albany, Albany, New York 12222.

+ Associate Professor, School of Criminal Justice, State University of New York at Albany.

** School of Justice Studies, Arizona State University, Tempe, Arizona.

1. See Lizotte \& Bordua, Firearms Ounership for Sport and Protection: Two Dizergent Models. 45 AM SOC. REv. 229 (1980).

2. Some researchers estimate the number of privately owned guns at between 100 and 140 million. J. Wright, P. Rossi \& K. Daly, Under the Gun: Weapons, Crime, and Viol.fence in AMERICA 41 (1983).

3. Public opinion polls conducted by both pro- and anti-control forces have found that the rast majority of respondents favor such mandatory sentences for gun crimes. See id. at 223, 227. Antigun control forces oppose mandatory sentences for possession or simply carrying a concealed firearm. but they support mandatory sentences for commission of a separate felony with a firearm. 
Mandatory sentencing or sentence enhancement for crimes committed with a gun are politically popular because they offer apparent means of controlling gun violence without imposing direct costs on legitimate gun owners. In principle, the costs are borne completely by criminals and by the criminal justice system in the form of longer sentences, more litigation, and so forth. ${ }^{4}$

Mandatory sentence enhancers for firearms crimes could reduce firearm crime rates in three ways. ${ }^{5}$ First, those receiving enhanced mandatory sentences may be deterred from committing crimes with firearms in the future. That is, having received an extra-long sentence for commission of a crime with a firearm, felons might choose to substitute other weapons for firearms. In effect, they would be hoping for shorter sentences if caught again. Criminologists refer to this as special or specific deterrence. Second, the mandatory sentence enhancers could have a general deterrence effect. People who have not yet committed a crime with a gun might substitute other weapons after becoming aware of longer sentences associated with gun use. Finally, there could be an incapacitative effect. Put simply, while gun criminals are serving their enhanced sentences they cannot participate in gun crimes. Hence, the crime rate would be reduced by the number of crimes they would have committed had they been set free.

Both deterrent effects rely on communication of the added cost of gun crime to the criminal, as well as on the criminal's evaluation of that cost as being too great to bear. In addition, the criminal must see a relatively high probability of receiving the enhanced sentence. To the extent that the enhanced punishment is not communicated to the potential criminal, the cost is evaluated as small, or the probability of enhanced punishment is seen as low, criminals may still choose to commit gun crimes. Unlike deterrence, however, the incapacitative effect occurs regardless of the offender's knowledge or evaluation. Thus, only judicial refusal to enforce the law can prevent a reduction in crime due to the sentence enhancer.

One might ask why either deterrence or incapacitation of gun criminals is desirable compared to deterrence or incapacitation of other criminals. This issue is especially critical in states with crowded prison systems. Given limited prison space, enhanced mandatory sentences for gun crimes means not incarcerating some nongun criminals who otherwise would have gone to prison. Resolving this issue requires asking if anything is gained by incarcerating gun, rather than nongun, criminals. Two pieces of evidence suggest that more benefits accrue from incarcerating gun criminals. First, gun criminals seem more likely to kill their victims than nongun criminals. For example, gun robbers are more likely to kill in the course of committing robbery than nongun robbers. ${ }^{6}$ This fact implies that lives would be saved because some gun robbers might shift to less deadly weapons and because

4. Loftin \& McDowall, One With a Gun Gets You Two: Mandatory Sentencing and Firearms liolence in Detroit. 445 AnNal.s 150, 163 (1981).

5. Loftin. Heumann \& McDowall, Mandatory Sentencing and Firearms Violence: Ezaluating an Allernative to Gun Control, 17 LAw \& Soc'y REv. 287, 303 (1983).

6. Cook, Reducing Injury and Death Rates in Robbery, 6 Pol. Analysis 21 (1980). 
convicted gun robbers who receive longer sentences would be incapacitated for longer periods. Similarly, Franklin E. Zimring reported that aggravated assaults committed with guns are more likely to result in death than nongun aggravated assaults. ${ }^{7}$ Incarcerating individuals who commit aggravated assaults with guns would presumably save lives due to the effects of special and general deterrence and incapacitation.

A second reason to support the incarceration of gun criminals is that some evidence suggests that gun criminals are disproportionately active in the criminal world. Researchers who conducted interviews with incarcerated gun criminals reported that:

In our analysis, the singular and distinguishing feature of the "high raters" is a pattern of gun involvement: men who have done more than a few crimes armed with a gun are in fact the most likely to have committed each and every kind of crime we asked about: assault, robbery, burglary, rape, drug dealing, and right down through the list. We refer to these men as Firearms Predators to emphasize the omnivorous character of their criminal activities. To say that they contribute disproportionately to the crime problem is a serious understatement. For all practical purposes, they are the crime problem in America today. ${ }^{8}$

\section{II}

\section{Recent Research on Firearms Sentence Enhancers}

Recently, several states have passed laws which mandate enhanced sentences for crimes committed with firearms. Shortly after one such law was implemented in California, Sheldon Messinger and Phillip Johnston reported on speculation about the possible effect of the law:

A major ambiguity and problem is whether the new statute will result in longer prison terms for most offenders; a related problem is whether it will result in the imprisonment of a greater proportion of convicted felons. The weight of opinion, after passage of the bill, was "yes" on both counts. ${ }^{9}$

Indeed, given the capacity of complex organizations to resist change, one might ask if these new laws are employed at all. A Massachusetts law provides an example of how the law can be circumvented. Massachusetts requires a mandatory one-year sentence for illegally carrying a firearm. ${ }^{10}$ The law removes discretion on sentence length from judges and parole boards. Kenneth Carlson reported that as a result of the law, however, the police "were now more selective about whom to frisk because they did not want to risk involving 'otherwise innocent' persons." 1 ' Of course, this would not have been a problem had the law enhanced the sentence on an additional felony

7. Zimring, Is Gun Control Likely to Reduce Violent Killings?, 35 U. CHi. L. Rev. 721, 728, 735 (1968)

8. J. Wright, The Illicit Firearms Market: Some Preliminary Results from a National Study 7 (1984) (unpublished manuscript) (available at Dep't of Sociology, Univ. of Mass., Amherst, Mass.).

9. Messinger \& Johnson, Califormia's Determinate Sentencing Statute: History and Issues, in Determinate Sentencing: Reform or Regression 30 (1978) (National Institute of Law Enforcement, Law Enforcement Assistance Administration).

10. Mass, Gen. Laws Ann. ch. 269, § 10(a) (West 1980).

11. Nat'l. Inst. of Justice, Dep't of Justice, Mandatory Sentencing: The Experience of Two States 6 (1982). 
instead of simple possession. Further, "in some instances an even greater degree of power was granted to arresting officers, who could decide when to look for a gun, and if they found one, whether to report."12 Some sentencing discretion "was transferred to the district attorneys since the charge at conviction now determined the length of the prison sentence if there was one." 13 In other words, to circumvent the law district attorneys could simply ignore the gun charge. Finally, even though the Massachusetts law removed all sentencing discretion from judges in gun cases, judges ${ }^{14}$ were apparently able to circumvent the law by increasing the proportion of not guilty verdicts on final dispositions. ${ }^{15}$ In Massachusetts it seems that limiting discretion at one point in the system (sentencing and parole) merely shifted discretion to other points (arrest, charge, guilt/innocence).

The Michigan felony firearm law provides another glimpse at mandatory sentence enhancers for firearms crime. In a series of papers, a group of researchers evaluated the effects of Michigan's Felony Firearm Statute in Wayne County (Detroit). ${ }^{16}$ The Michigan law imposed a two-year mandatory add-on sentence for defendants convicted of possession of a firearm while committing a felony. ${ }^{17}$ The introduction of the law was well publicized. Because the law mandates an add-on sentence for those who commit a felony with a gun, Detroit police had no reason to circumvent the law. That is, they had no reason to believe that the person possessing the firearm was "otherwise innocent," as in the Massachusetts case. Moreover, the Wayne County prosecutor refused to bargain on the firearms charge. Thus, the Michigan Felony Firearm Law, as applied in Wayne County, provided a natural experiment in which sentencing discretion was not allowed to shift from judges and parole boards to prosecutors and police officers.

Despite strict application of the Michigan law, no difference was observed in the average length of prison sentences assigned to gun criminals before and after imposition of the law. This lack of change in the average sentence for gun crimes could reflect either no change in sentencing policy, or no change in sentencing practice for gun crimes with shorter sentences for nongun crimes after the law took effect. In the latter case judges would be following the letter of the law: Gun felons would be assigned longer sentences. Further analysis, however, showed that after implementation of the law there was no difference in prison sentence length assigned to nongun, as opposed to gun, offenders. How did the Detroit courts avoid assigning the extra mandatory sentence?

12. Nat'l Inst. of Justice, Dep't of Justice, supra note 11 , at 3.

13. Id.

14. These are judges' and not jurors' decisions since the vast majority of not guilty verdicts result from bench trials.

15. Nat'l. InSt. Of Justice, Dep't of Justice, supra note 11 , at 7.

16. Heumann \& Loftin, Mandatory Sentencing and the Abolition of Plea Bargaining: The Michigan Felony Firearms Statute, 13 LAw \& Soc'y Rev. 40 (1979); Loftin, Heumann \& McDowall, supra note 5; Loftin \& McDowall, supra note 4.

17. Мiсн. Сомp. Laws ANN. $\$ 750.227$ b (West Supp. 1985). 
The notion of a rough tariff, or going rate, for specific crime/criminal combinations structured the courts' response to the Gun Law in two ways. In serious cases which, even prior to the Gun Law, would have resulted in substantial time in prison, sentences on the primary felony were adjusted downward to compensate for the twoyear Gun Law increment. ${ }^{18}$

In less serious cases, which would have received less than two years of prison before the Michigan gun law took effect, judges used three tactics: "Among the options open to a judge were to find a defendant completely innocent, to find him/her guilty of the felony but not of the Gun Law charge, or to find him/her guilty of a misdemeanor, in which case the felony firearm count automatically disappeared."19 Given the way that sentencing on the Michigan Felony Firearm Law was subverted, it is not surprising that the researchers found that the law had no effect on Detroit's gun crime rates. ${ }^{20}$

Nevertheless, Loftin, Heumann, and McDowall speculated that the Michigan gun law may have been used against the most serious repeat offenders, that is, to "throw the book" at "bad guys." 21 They could not validate this suspicion because they lacked data on sentencing for second and later convictions under the Michigan gun law. ${ }^{22}$ The researchers suggest, however, that "courts faced with such serious offenders are less concerned with the going rate. Thus, sentences which were high prior to the Gun Law may, after the Gun Law, be even higher."'23 They point out that if the parole board reduces the time actually served for good conduct in prison, even this effect of the law could be thwarted. Additionally, since they considered only a twelve-month period after implementation of the gun law, the researchers speculated that a longer interval of study may show the law to be more effective with the passage of time. ${ }^{24}$

The research reported here attempts to address the deficiencies in the Detroit studies. Data from a period of up to three years after the enactment of a mandatory sentence enhancer for gun crimes are used. The longitudinal approach allows a determination of whether these gun laws become more effective as time passes. Second, this study includes defendants processed for first and later arrests in order to determine whether such laws are used to "throw the book" at "bad guys."

Data on criminal sentencing from the state of California are used in this analysis. Since 1977, California law has required mandatory gun crime sentence enhancement. The law does not allow prison sentences to be shortened for "good time" served. California law mandates an additional one-year prison sentence if a person or that person's accomplice is armed with a firearm in the commission or attempted commission of a felony. ${ }^{25}$ If a

18. Loftin, Heumann \& McDowall, supra note 5, at 298.

19. Id. at 301 .

20. Id.

21. Id. at 300 .

22. They did not know whether defendants had prior records.

23. Loftin, Heumann \& McDowall, supra note 5, at 300.

24. Loftin \& McDowall, supra note 4, at 163

25. Cal. Penal Code $\$ 12022$ (West 1982). 
person actually uses a gun in an attempted or completed felony, the additional sentence is two years. ${ }^{26}$ For sex offences, simply being armed dictates two additional years, while using a firearm adds a third year to the prison sentence. ${ }^{27}$ The remainder of this article evaluates this set of California laws.

III

Data And Methods

\section{A. Data}

The data for this study were obtained from the State of California, Department of Justice, Bureau of Criminal Statistics. The data base consists of longitudinal histories of the processings of individuals through the criminal courts. All defendants arrested for felonies in California whose cases reached disposition by the police, prosecutor, or court in 1977, 1978, and 1979 are included. Arrests could have occurred during this three-year period or earlier. The processing histories include information regarding every time any given individual entered, exited, and reentered the system during the three-year period. The greatest number of arrests reaching disposition in the three-year period for any given individual was fifteen. Processing histories allow for evaluation of the effects of California's gun law for first-time, as well as repeat, offenders. ${ }^{28}$ Accordingly, each sequential arrest and rearrest of an individual is analyzed separately. The data include information on both the offense and the offender. Also included are variables reflecting the processing of the case through the criminal justice system and the dates of arrest and disposition. These dates are used to measure the length of time required to process the case.

Only those defendants found guilty of a felony and sentenced to prison are included in the analysis. Because the firearms enhancer refers only to prison sentences, cases in which the sentence was suspended or probated without any incarceration are excluded. In California, prison sentences are reserved for those convicted of felonies; misdemeanants receive jail, probation, and other more lenient sentences. For defendants with multiple charges, only the most serious charge (as defined by the California State Department of Justice) is available. This situation is not as problematic as it might at first appear because offenses involving firearms generally receive high severity codings. While arrest and conviction charges may differ, sentencing is based on the conviction charge. Since the interest here is sentencing practices, only the conviction charge is analyzed. ${ }^{29}$

26. Cal. Penal Code $\S 12022.5$ (West Supp. 1984).

27. Cal. Penal Code $\$ 12022.3$ (West 1982).

28. In this study, repeat offenders are those who were processed and convicted by the California courts more than once in the three-year study period. Therefore, arrests and convictions before 1977 are not considered, potentially making estimates of the number of repeat processings for any given criminal low.

29. The arrest and the conviction charge can be different due to "charge bargaining" between the prosecutor and defendant. 
The data set is so large that all 450,000 cases could not be included. To make the analyses more manageable, random samples were drawn from the populations of first arrests, second arrests, and so on for each sequential arrest of the same individual. More specifically, a three percent random sample of all first arrests (regardless of whether the person was later rearrested) resulted in 10,892 cases. Similarly, a ten percent sample of all second arrests within the three-year period resulted in 2886 cases. A thirty percent sample of third arrests yielded 1794 cases, and a seventy-five percent sample of fourth arrests resulted in 1232 cases. Finally, all fifth and later arrests were combined into a sample of 736 cases. From these five samples, cases not resulting in conviction and a prison sentence were excluded, reducing the samples to $313,149,124,95$, and 66 cases, respectively.

The coding of variables is relatively straightforward. The dependent variable is the length of prison sentence in months. Life sentences are coded as 600 months (fifty years) for those few defendants sentenced for life. This coding is based on the assumption that the typical murderer is in his or her twenties and will live into his or her seventies. Most of the independent variables are binary coded, with comparisons made between the category coded one and the category coded zero. The zero group serves as a "reference category." For example, gender is coded one for females and zero for males, allowing for determination of the effect of being female, compared with being male, on sentence length.

Race/ethnicity is coded into two dummy variables. ${ }^{30}$ The effects on sentence length of being Black and of being Chicano are compared with being White. That is, for one variable Blacks are coded one and Whites and Chicanos zero, and for the second Chicanos are coded one and Whites and Blacks zero. By always coding Whites as zero, they serve as a reference point for any effects of being Black or Chicano: Comparisons are made between Blacks and Whites, and then between Chicanos and Whites. The decision to separate Blacks and Chicanos, rather than to treat all nonwhites as one group, is based on differences found by Marjorie Zatz in sentence lengths for these two groups. ${ }^{31}$ Joan Petersilia also found differences between these racial/ethnic groups in use of guns or knives. ${ }^{32}$ These studies were based on similar California data. Use of two dummy variables (for Blacks and for Chicanos), both in comparison with Whites, avoids confounding differences between ethnic groups with the influence of using firearms. In this way, the rival effects of race/ethnicity can be statistically held constant, thereby clarifying the true relationship between use of firearms and sentence length.

Similarly, age is coded into two dummy variables with first "Young" (eighteen to twenty years of age) and then "Old" (forty-one years of age and over) offenders coded one, and everyone else coded zero. The twenty-one to

30. "Dummy variables" are binary coded variables (i.e., 0 or 1 ).

31. Zatz, Race, Ethnicity, and Determinate Sentencing: A Vext Dimension to an Old Comtronersy. 22) Criminology 147,165 (1984).

32. J. Petersilia, Racial Disparities in the Criminal Justice Sistem xxi, 78,80 (1983). 
forty year old group serves as the reference category. The age categories are based on the percentages of offenders in the sample; the Young and Old categories capture the extremes, with approximately seventy percent of the defendants falling between twenty-one and forty years of age. Such categorizations are more useful than treating age as a continuous variable; differences between groups of defendants are more important to sentencing patterns than the effect of a one-year increment in age.

The type of offense is also binary-coded, resulting in nine dummy variables. The appropriate variable is coded one if the person is convicted of homicide, assault, burglary, theft, auto theft, forgery, rape, narcotics violations, or some other felony. Each of these crime types is compared to a robbery conviction. For each variable, the remaining eight crime categories, along with robbery, are coded zero. The "other felony" category includes those varied offenses not listed above (kidnapping, bribery, and pimping, for example). The offense categorizations roughly follow the three-digit offense code used by the State of California Departments of Justice and Corrections, with some adjustments made for the relative frequencies of these offenses in the sample analyzed (for example, "homicide" includes both murder and manslaughter).

"Firearm" is also coded as a dummy variable. Zero indicates that the defendant did not use a firearm in the commission of the offense, while a code of one indicates that he or she did use a firearm. "Possession" is dummycoded as well, with zero indicating no possession of contraband and a code of one meaning that the charge included possession. The only instances in which both of these variables receive codes of one are possession or sale of a machine gun, bringing guns into a jail, prison, or roadcamp, and possession of a loaded weapon. ${ }^{33}$

Offense severity is an integer scale which ranges in value from one through nine, with a value of one reflecting the least severe offenses and nine reflecting the most serious crimes. This scale is a collapsed and reversed version of the severity scale used by the State of California, Department of Justice and is based on the specific offense involved, not the categories discussed above. For example, within the "homicide" category, murder has a severity score of nine, manslaughter has a score of six, and vehicular manslaughter with and without negligence have scores of two and one, respectively. While the validity of this scale may vary for other states, it has great validity for California courts since it was created and is used by the California Department of Justice.

Offense specialization is also examined here. Several researchers have examined crime specialization. ${ }^{34}$ Their analyses, however, were limited to

33. None of these offenses carries the enhanced mandatory sentence because possession does not include or imply use. By controlling for these crimes in the possession variable their effects are excluded from the firearm variable, as they should be.

34. See M. Wolfgang, R. Figlio \& T. Sellin, Delingufncy in a Birti Cohort 206 (1972): Bursik, The Dynamics of Specialization in Juvenile Offenses, 53 Soc. ForCes 851 (1980); Rojek \& Erickson. Delinquent Careers: A Test of the Career Escalation Model, 20 Criminolocy 5, 13-16 (1982). 
assessing the predictive power of the most recent offense type on the current type of offense. They used simple Markov models in which only the immediate prior offense is included. The limitation of this procedure is apparent if one considers a hypothetical defendant arrested four times for narcotics, a fifth time for robbery, and a sixth time for narcotics. When examining the sixth offense, simple Markov models would not consider the defendant to be a specialist in narcotics. Yet, five of the six arrests were for narcotics. The offense specialization scale used here is more sensitive. It is constructed on the basis of all prior arrests and measures the extent to which individuals specialize in the type of offense for which they are currently charged, considering all earlier offenses. The scale ranges in value from 0.0 through 1.0, with a value of 0.0 reflecting no specialization whatsoever, and a value of 1.0 meaning that every arrest was for the same type of offense as that currently charged. For example, rather than arbitrarily excluding the hypothetical defendant described above simply because of the intervening robbery arrest, the scale would assign this person a value of 0.86 in narcotics specialization. The type of case disposition is coded into two dummy variables reflecting cases resolved by guilty pleas and by juries. Bench trials serve as the reference category for both variables. That is, the plea variable cases that reached disposition by guilty plea are coded one and cases that go to trial are coded zero. For the jury trial variable, cases resolved by jury are coded one and cases decided by bench trials or guilty pleas are coded zero. The effects of disposition by a plea of guilty and by jury trial are thus separately contrasted with case disposition by a judge. Knowledge of who decided the case provides some information on how the case was handled, even though specific sentence recommendations (as to inclusion of mitigating or aggravating circumstances) are not available.

Finally, the time required to process the case from arrest to disposition and sentencing is measured in days. Bail status and time in detention were not included in the data set. Persons detained for a lengthy time may be especially willing to offer a plea, however, and the plea variable captures this effect. Also, detention time is related to the length of time the case is in the system, and this latter variable is included in the analyses.

\section{B. Methods}

If the firearms sentence enhancement is applied, then defendants who use a firearm in committing offenses will have at least an additional year added to their sentences. ${ }^{35}$ To determine if it is indeed the use of a firearm that incurs this additional time, the cases must be rendered equivalent on all rival factors, thereby eliminating the impact of these factors on the relationship of interest (the effect of firearm use on prison sentence length). This equivalency is accomplished through Ordinary Least Squares multiple regression analysis.

35. A statistically significant addition to prison sentences of less than one year would imply that the law is not employed in every case, or that judges are enhancing sentcnces by less than what the law mandates. 
Multiple regression is a comprehensive and general approach to the analysis of relationships among variables. It makes possible prediction of the effect that a change in the value of an independent variable (e.g., firearm versus nonfirearm) would have on the value of the dependent variable (prison sentence in months). This procedure statistically removes distorting influences caused by other independent variables, thus allowing for estimation of the separate effects of each independent variable on sentence length.

Ordinary Least Squares regression involves fitting a line to the data that minimizes the amount of error in estimation. Estimates of the effects of independent variables on the dependent variable are provided by the multiple regression coefficients. These coefficients indicate the amount of increase (if positive) or decrease (if negative) in the dependent variable for a one-unit difference in the independent variable of interest, controlling for the other variables in the equation. The one-unit difference refers to the coding of the variables. For example, the dependent variable (prison sentence length) is measured in months, and the firearms variable is coded one for those using a firearm and zero for those not using a firearm. Thus, the regression coefficient for firearms use translates into the additional months added to the sentence for persons who used a firearm, compared with those who did not use a firearm.

If the coefficient is twelve (months) or greater, and is statistically significant, then the law is being upheld. If it is not significant or is less than twelve, then the law is not being applied. Tests of statistical significance are rules that aid in deciding whether to accept or reject the hypothesis that a given effect differs greatly from zero. The tests reveal how likely it is that conclusions based on a sample also hold true for the population from which the sample was selected. If an effect is statistically significant, then the effect is probably "real" and not an artifact of chance or random factors. No effect is absolutely significant or absolutely nonsignificant; rather, significance levels are used which refer to the probability that an error would occur in saying that an effect differs from zero. In the social sciences, this level is conventionally set at .05 or lower, meaning that only five (or fewer) times out of 100 would this effect result from chance alone. Some coefficients might appear quite large, but still not be statistically significant. In such cases, the standard error of the estimate is also large, making the measured effect likely to be the result of chance factors and not really true in the population at large. For this reason, it is important to consider the statistical significance of the effect as well as its size and substantive importance.

\section{IV}

\section{Analyses}

The analyses test the impact of the use of a firearm in committing a crime on sentencing practices in California. Rival factors that might explain prison sentence length are held constant. That is, the distorting influences of 
race/ethnicity, gender, age, offense type, offense severity, evidence of possession, type of disposition, time in the system, and crime specialization (for second or later offenses) are statistically removed. If firearms use is found to be statistically significant, and if it adds at least one year to felony sentences, then it can be concluded that the California firearm sentence enhancer is used by the courts.

Table 1 shows the Ordinary Least Squares equation predicting prison sentence length for all defendants for their first pass through the criminal justice system. Controlling for the severity of the offense, firearms use, and other relevant factors, the equation shows that the defendants convicted of homicide, burglary, theft, auto theft, and other felonies receive significantly longer sentences than defendants convicted of robbery (the reference category). ${ }^{36}$ Similarly, the more serious the offense, the longer the prison sentence. Cases resolved by guilty pleas and by juries also receive significantly shorter sentences than bench trials. The finding that a guilty plea results in shorter sentences is consistent with most prior research; the efficiency of guilty pleas is generally found to be rewarded with lenient sentences. Less attention has been paid to jury versus bench trials. It is likely that jurors are less jaded than judges, however, and that they accordingly recommend shorter sentences. This finding is not specific to Ordinary Least Squares analysis, since Marjorie Zatz and John Hagan found a similar effect using a different analytic technique. ${ }^{37}$ Characteristics of the defendant (such as race/ethnicity, age, or gender), evidence of possession, and time in the system do not significantly affect sentence length for first arrests.

36. Again, these relations exist independently of other factors which have been statistically controlled. In part, this finding means that, after removing the impact of the severity of the offense on sentence length, homicide, burglary, theft, and auto theft receive significantly longer sentences than robbery.

37. Zatz \& Hagan, Crime, Time and Punishment: An Exploration of Selection Bins in Sentencing Reserarch. $1 \mathrm{~J}$. Quantitative Criminology 103 (1985). 
TABLE 1

Regression of Sentence Length on Exogenous Factors, First Arrests

\begin{tabular}{|c|c|c|c|c|c|}
\hline & b & se. of $b$ & $\beta$ & $\overline{\mathrm{x}}$ & s.d. \\
\hline \multicolumn{6}{|l|}{ Race/Ethnicity } \\
\hline Chicano & -10.34 & 10.45 & -0.05 & 0.25 & 0.44 \\
\hline Black & 1.27 & 9.60 & 0.01 & 0.35 & 0.48 \\
\hline Whitea & & & & & \\
\hline Female & -26.42 & 18.95 & -0.07 & 0.05 & 0.23 \\
\hline \multicolumn{6}{|l|}{ Age } \\
\hline Young (18-20) & 25.30 & 17.47 & 0.06 & 0.06 & 0.23 \\
\hline Old $(41+)$ & -25.96 & 15.33 & -0.08 & 0.08 & 0.27 \\
\hline Middle-aged" & & & & & \\
\hline \multicolumn{6}{|l|}{ Offense Type } \\
\hline Homicide & $61.45^{* *}$ & 18.88 & 0.18 & 0.08 & 0.27 \\
\hline Assault & 16.72 & 16.27 & 0.05 & 0.09 & 0.28 \\
\hline Burglary & $52.48^{* * *}$ & 14.85 & 0.24 & 0.23 & 0.42 \\
\hline Theft & $64.25^{* *}$ & 20.29 & 0.18 & 0.07 & 0.26 \\
\hline Auto Theft & $64.62 *$ & 29.77 & 0.11 & 0.02 & 0.15 \\
\hline Forgery & 27.37 & 30.26 & 0.06 & 0.04 & 0.20 \\
\hline Rape & 4.69 & 21.51 & 0.01 & 0.05 & 0.21 \\
\hline Narcotics & -5.58 & 19.48 & -0.02 & 0.11 & 0.31 \\
\hline Other Felony & $39.47^{*}$ & 16.95 & 0.12 & 0.09 & 0.28 \\
\hline Robberya & & & & & \\
\hline Firearm Used & -9.99 & 16.64 & -0.03 & 0.07 & 0.26 \\
\hline Possession & 24.82 & 21.67 & 0.09 & 0.11 & 0.32 \\
\hline Offense Severity & $25.69 * * *$ & 3.33 & 0.57 & 4.05 & 2.04 \\
\hline \multicolumn{6}{|l|}{ Mode of Disposition } \\
\hline Plea & $-151.88^{* * *}$ & 25.00 & -0.60 & 0.85 & 0.36 \\
\hline Jury & $-107.21^{* * *}$ & 26.92 & -0.39 & 0.12 & 0.33 \\
\hline Judge & & & & & \\
\hline Process Time in Days & 0.03 & 0.04 & 0.03 & 151.82 & 96.11 \\
\hline (Constant) & 62.58 & 33.27 & & & \\
\hline Prison Sentence Length & & & & 55.78 & 91.01 \\
\hline$N=313$ & \multicolumn{2}{|c|}{$\mathrm{F}=11.84^{* * *}$} & adj 1 & $\begin{array}{l}.45 \\
.41\end{array}$ & \\
\hline
\end{tabular}

* Sig at $\mathrm{P} \leq .05$.

**Sig at $\mathrm{P} \leq .01$.

$* *$ Sig at $\mathrm{P} \leq .001$.

:Reference category.

Despite the mandated sentence enhancer, use of a firearm does not significantly affect the length of sentence to prison. In fact, the effect is in the opposite direction from that which would be expected if the enhancer were applied: Use of a firearm has a slight (and nonsignificant) negative impact on sentence length when the type of offense, its severity, and other factors are made equivalent for all cases. These results suggest that the type and severity of the offense, as well as the method of case disposition, have the greatest effects on sentencing. 
Table 2 refines the analysis reported in Table 1 by excluding crimes not likely to involve a gun. Because these nongun offenses may generate "noise" (i.e., variation due to uncontrolled factors) that could mask the firearms effect, the equation is respecified with only homicide, rape, burglary, assault, and robbery convictions included. Once again, homicide and burglary increase the sentence length compared with robbery, serious offenses receive longer sentences than less serious offenses, and cases that are resolved by a guilty plea receive lighter sentences than those decided by judges. In addition, controlling for other factors, use of firearms again has a nonsignificant negative effect on prison sentence length.

\section{TABLE 2}

Regression of Sentence Length on Exogenous Factors, First Arrests, for Homicide, Rape, Burglary, Assault, and ROBbery Convictions

\begin{tabular}{|c|c|c|c|c|c|}
\hline & b & se. of $b$ & $\beta$ & $\overline{\mathrm{X}}$ & s.d. \\
\hline \multicolumn{6}{|l|}{ Race/Ethnicity } \\
\hline $\begin{array}{l}\text { Chicano } \\
\text { Black } \\
\text { White }^{\text {a }}\end{array}$ & $\begin{array}{r}-20.07 \\
1.88\end{array}$ & $\begin{array}{l}14.20 \\
12.31\end{array}$ & $\begin{array}{r}-0.09 \\
0.01\end{array}$ & $\begin{array}{l}0.22 \\
0.37\end{array}$ & $\begin{array}{l}0.42 \\
0.48\end{array}$ \\
\hline $\begin{array}{l}\text { Female } \\
\text { Age }\end{array}$ & -57.45 & 46.15 & -0.07 & 0.01 & 0.12 \\
\hline $\begin{array}{l}\text { Young }(18-20) \\
\text { Old } \quad(41+) \\
\text { Middle-aged }\end{array}$ & $\begin{array}{r}9.95 \\
-20.10\end{array}$ & $\begin{array}{l}20.05 \\
24.90\end{array}$ & $\begin{array}{r}0.03 \\
-0.05\end{array}$ & $\begin{array}{l}0.08 \\
0.05\end{array}$ & $\begin{array}{l}0.27 \\
0.22\end{array}$ \\
\hline \multicolumn{6}{|l|}{ Offense Type } \\
\hline $\begin{array}{l}\text { Homicide } \\
\text { Rape } \\
\text { Burglary } \\
\text { Assault } \\
\text { Robberya }\end{array}$ & $\begin{array}{l}57.06^{*} \\
1.49 \\
54.32^{* *} \\
17.20\end{array}$ & $\begin{array}{l}23.30 \\
24.82 \\
18.73 \\
17.91\end{array}$ & $\begin{array}{l}0.19 \\
0.00 \\
0.27 \\
0.06\end{array}$ & $\begin{array}{l}0.12 \\
0.07 \\
0.35 \\
0.13\end{array}$ & $\begin{array}{l}0.33 \\
0.26 \\
0.48 \\
0.34\end{array}$ \\
\hline Firearm Used & -14.21 & 19.70 & -0.04 & 0.09 & 0.28 \\
\hline Possession & - & - & - & 0 & 0 \\
\hline Offense Severity & $26.80 * * *$ & 5.24 & 0.56 & 4.39 & 2.01 \\
\hline \multicolumn{6}{|l|}{ Mode of Disposition } \\
\hline $\begin{array}{l}\text { Plea } \\
\text { Jury } \\
\text { Judgea }\end{array}$ & $\begin{array}{l}-132.73^{* *} \\
-72.88\end{array}$ & $\begin{array}{l}44.86 \\
46.55\end{array}$ & $\begin{array}{l}-0.48 \\
-0.25\end{array}$ & $\begin{array}{l}0.86 \\
0.12\end{array}$ & $\begin{array}{l}0.35 \\
0.33\end{array}$ \\
\hline Process Time in Days & 0.03 & 0.05 & 0.03 & 153.58 & 101.64 \\
\hline (Constant) & 41.16 & 53.46 & & & \\
\hline $\begin{array}{r}\text { Prison Sentence Length } \\
\qquad N=209\end{array}$ & \multicolumn{2}{|c|}{$\mathrm{F}=9.93^{* * *}$} & \multicolumn{3}{|c|}{$\begin{array}{r}R^{2}=.42 \\
\text { adj } R^{2}=.38\end{array}$} \\
\hline $\begin{aligned} * \text { Sig at } \mathrm{P} \leq .05 \\
{ }^{* *} \text { Sig at } \mathrm{P} \leq .01 \\
* * * \text { Sig at } \mathrm{P} \leq .001 \\
\text { "Reference category. }\end{aligned}$ & & & & & \\
\hline
\end{tabular}


Because sentence length varies by the type of offense (which is reasonable under determinate sentencing guidelines), it is possible that the type of offense might mask and interact with the effect of using a firearm. Accordingly, analyses are conducted separately for first arrests that were robbery, assault, and homicide convictions. Rapes and burglaries are excluded since none of the first arrests resulting in convictions for these offenses involved firearms. It is possible that for these cases a firearm was indeed used but that this part of the charge was dropped during plea bargaining or in exchange for a waiver of the speedy trial stipulations. The results for robbery convictions are reported in Table 3. A small positive effect for firearms use is now visible. Since this effect is not significant, however, we must again conclude that use of a firearm has no impact on prison sentence lengths.

\section{TABLE 3}

Regression of Sentence Length on Exogenous Factors, First ARrests, for RobBery Convictions

\begin{tabular}{|c|c|c|c|c|c|}
\hline \multirow{2}{*}{\multicolumn{6}{|c|}{ Race/Ethnicity }} \\
\hline & & & & & \\
\hline \multirow{3}{*}{$\begin{array}{l}\text { Chicano } \\
\text { Black } \\
\text { White }\end{array}$} & -0.99 & 6.41 & -0.02 & 0.23 & \\
\hline & -3.27 & 5.40 & -0.09 & 0.42 & \\
\hline & & & & & \\
\hline Female & - & 一 & - & 0 & \\
\hline \\
\hline Young (18-20) & 6.74 & 7.67 & 0.11 & 0.10 & \\
\hline Old $(41+)$ & - & - & - & 0 & \\
\hline \multicolumn{5}{|l|}{ Middle-ageda } & \\
\hline Firearm Used & 4.97 & 5.89 & 0.10 & 0.19 & \\
\hline Possession & - & - & 一 & 0 & \\
\hline Offense Severity & -19.84 & 12.49 & -0.22 & 4.96 & \\
\hline \multicolumn{5}{|l|}{ Mode of Disposition } & \\
\hline Plea & $30.71^{*}$ & 15.29 & 0.62 & 0.83 & \\
\hline Jury & $34.85^{*}$ & 16.18 & 0.65 & 0.15 & \\
\hline \multicolumn{5}{|l|}{ Judgea } & \\
\hline Process Time in Days & 0.03 & 0.03 & 0.13 & 138.54 & \\
\hline (Constant) & $115.08^{*}$ & 57.09 & & & \\
\hline \multicolumn{3}{|l|}{ Prison Sentence Length } & & 51.71 & 18 \\
\hline $\mathrm{N}=69$ & \multicolumn{2}{|c|}{$F=1.05$} & \multicolumn{2}{|c|}{$\begin{array}{r}\mathbf{R}^{2}=.12 \\
\text { adj } \mathbf{R}^{2}=.01\end{array}$} & \\
\hline
\end{tabular}


Similarly, results reported in Table 4 and Table 5 demonstrate that defendants who assault or kill with firearms are given sentences that are statistically identical to those for persons who commit these crimes without guns. The mandatory sentence enhancer is simply not used for first convictions of any type. Instead, the severity of the offense has the greatest influence on sentence length, even within crime categories.

\section{TABLE 4}

Regression of Sentence Length on Exogenous Factors, First Arrests, for Assault Convictions

\begin{tabular}{|c|c|c|c|c|c|}
\hline & $\mathrm{b}$ & se. of $b$ & $\beta$ & $\overline{\mathrm{x}}$ & s.d. \\
\hline \multicolumn{6}{|l|}{ Race/Ethnicity } \\
\hline $\begin{array}{l}\text { Chicano } \\
\text { Black } \\
\text { Whitea }\end{array}$ & $\begin{array}{l}5.99 \\
4.74\end{array}$ & $\begin{array}{l}8.46 \\
6.68\end{array}$ & $\begin{array}{l}0.17 \\
0.16\end{array}$ & $\begin{array}{l}0.26 \\
0.52\end{array}$ & $\begin{array}{l}0.45 \\
0.51\end{array}$ \\
\hline $\begin{array}{l}\text { Female } \\
\text { Age }\end{array}$ & -9.15 & 14.91 & -0.11 & 0.04 & 0.19 \\
\hline $\begin{array}{l}\text { Young }(18-20) \\
\text { Old }(41+) \\
\text { Middle-aged }\end{array}$ & $\begin{array}{r}3.66 \\
-4.50\end{array}$ & $\begin{array}{r}10.24 \\
9.71\end{array}$ & $\begin{array}{r}0.06 \\
-0.09\end{array}$ & $\begin{array}{l}0.07 \\
0.11\end{array}$ & $\begin{array}{l}0.27 \\
0.32\end{array}$ \\
\hline Firearm Used & 14.11 & 9.54 & 0.24 & 0.07 & 0.27 \\
\hline Possession & & & & 0 & 0 \\
\hline Offense Severity & $6.59^{* *}$ & 1.93 & 0.56 & 4.33 & 1.30 \\
\hline \multicolumn{6}{|l|}{ Mode of Disposition } \\
\hline $\begin{array}{l}\text { Pleab }^{\mathrm{b}} \\
\text { Jury } \\
\text { Judgea }\end{array}$ & $22.08^{*}$ & 8.35 & 0.46 & $\begin{array}{l}0.89 \\
0.11\end{array}$ & $\begin{array}{l}0.32 \\
0.32\end{array}$ \\
\hline Process Time in Days & 0.03 & 0.03 & 0.16 & 149.96 & 90.21 \\
\hline (Constant) & 3.73 & 11.88 & & & \\
\hline $\begin{array}{l}\text { Prison Sentence Length } \\
\qquad N=27\end{array}$ & \multicolumn{2}{|c|}{$F=2.99^{*}$} & \multicolumn{3}{|c|}{$\begin{aligned} R^{2} & =.61 \\
\operatorname{adj} R^{2} & =.41\end{aligned}$} \\
\hline $\begin{array}{l}{ }^{*} \text { Sig at } \mathrm{P} \leq .05 \\
{ }^{*} \text { Sig at } \mathrm{P} \leq .01 \\
\text { a Reference category. }\end{array}$ & & & & & \\
\hline
\end{tabular}


TABLE 5

Regression of Sentence Length on Exogenous Factors, First Arrests, for Homicide Convictions

\begin{tabular}{|c|c|c|c|c|c|}
\hline & b & se. of $b$ & $\beta$ & $\overline{\mathrm{x}}$ & s.d. \\
\hline \multicolumn{6}{|l|}{ Race/Ethnicity } \\
\hline $\begin{array}{l}\text { Chicano } \\
\text { Black } \\
\text { Whitei }\end{array}$ & $\begin{array}{r}-34.29 \\
135.61\end{array}$ & $\begin{array}{l}125.95 \\
112.87\end{array}$ & $\begin{array}{r}-0.06 \\
0.23\end{array}$ & $\begin{array}{l}0.20 \\
0.16\end{array}$ & $\begin{array}{l}0.41 \\
0.37\end{array}$ \\
\hline $\begin{array}{l}\text { Female } \\
\text { Age }\end{array}$ & 2.18 & 145.66 & 0.00 & 0.08 & 0.28 \\
\hline $\begin{array}{l}\text { Young }(18-20) \\
\text { Old }(41+) \\
\text { Middle-ageda }\end{array}$ & $\overline{27.33}$ & $\overline{128.37}$ & $\overline{0.05}$ & $\begin{array}{c}0 \\
0.16\end{array}$ & $\begin{array}{c}\mathbf{0} \\
0.37\end{array}$ \\
\hline Firearm Used & -124.21 & 157.91 & -0.19 & 0.12 & 0.33 \\
\hline Possession & - & - & - & 0 & $\mathbf{0}$ \\
\hline Offense Severity & $41.49^{*}$ & 23.31 & 0.38 & 7.16 & 2.04 \\
\hline \multicolumn{6}{|l|}{ Mode of Disposition } \\
\hline $\begin{array}{l}\text { Plea } \\
\text { Jury } \\
\text { Judgea }\end{array}$ & $\begin{array}{l}-420.11^{* *} \\
-255.22\end{array}$ & $\begin{array}{l}196.55 \\
192.12\end{array}$ & $\begin{array}{l}-0.91 \\
-0.53\end{array}$ & $\begin{array}{l}0.68 \\
0.28\end{array}$ & $\begin{array}{l}0.48 \\
0.46\end{array}$ \\
\hline Process Time in Days & 0.12 & 0.34 & 0.07 & 231.64 & 125.75 \\
\hline (Constant) & 200.70 & 269.44 & & & \\
\hline Prison Sentence Length & & & & 172.00 & 220.33 \\
\hline$N=25$ & \multicolumn{2}{|c|}{$F=2.60^{* *}$} & \multicolumn{3}{|c|}{$\begin{array}{r}\mathbf{R}^{2}=.61 \\
\mathbf{R}^{2}=.38\end{array}$} \\
\hline
\end{tabular}

* Sig at $\mathrm{P} \leq .10$.

** Sig at $\mathrm{P} \leq .05$.

aReference category.

What might account for these findings? First, the number of cases resulting in prison sentences for each of these offense types is small. This limitation is important because statistically significant results are obtained more easily with large numbers of cases.

Second, sentence length is greatly influenced by the type and severity of the offense and by the method of case disposition, and these rival factors are held constant here. Therefore, we are looking at a weak (that is, conservative) test of our hypothesis. For these cases, the use of firearms was not dropped as a condition for waiving the speedy trial stipulation, nor was the case bargained down to exclude the firearms aspect of the offense.

Third, a number of studies have found that crimes committed with knives tend to involve more injury than those committed with guns. ${ }^{38}$ Judges may be more responsive to the amount of injury than to the use of a gun per se.

38. See J. Conklin, Robbery and the Criminal Justice System 117 (1972); F. Feeney \& A. Weir, The Prevention and Control of Robbers: A Summary 77 (1974); Cook. Reducing Injuy and Dealh Rates in Robbery, 6 Pol.'Y Anat.ysis 21, 33 (1980); Zimring, supra note 7, at 732-33, 734 (measuring the seriousness or violence of an attack by the location of the wound). 
Finally, it may be that first offenders, even those using a gun, are "given a break" by the courts. If repeat offenders are considered particularly dangerous or incorrigible, then the firearms enhancer might be used only for those persons displaying more of a career orientation to crime. The latter hypothesis is tested in the next analyses.

Equations predicting prison sentence length are estimated for defendants who made two, three, four, and five or more passes through the California courts for felony offenses in the three years under consideration. In addition to the variables included in the earlier equations, the degree of crime specialization across all earlier arrests is controlled for in these analyses.

Table 6 and Table 7 demonstrate that for second and third arrests, use of a firearm still has no effect on the length of prison sentence. While the prior offenses may or may not have involved firearms, for second arrests the offense specialization variable is positive and significant. The coefficient for specialization means that defendants convicted of the same type of offense for their first and second arrests receive sentences twenty-five months longer than similar defendants whose first and second convictions differ in type. Also, controlling for all other factors, second arrests resulting in convictions for assault receive longer sentences than convictions for robbery. Furthermore, the longer the time required to process the case through the system, the longer the sentence. Again, this suggests that defendants are penalized for taxing court resources. For third arrests, the severity of the offense is the only variable in the equation to increase sentence length. 
TABLE 6

Regression of Sentence Length on Exogenous factors, SECOND ARrests

\begin{tabular}{|c|c|c|c|c|c|}
\hline & b & se. of $b$ & $\beta$ & $\overline{\mathrm{x}}$ & s.d. \\
\hline \multicolumn{6}{|l|}{ Race/Ethnicity } \\
\hline Chicano & 9.04 & 11.70 & 0.07 & 0.22 & 0.41 \\
\hline $\begin{array}{l}\text { Black } \\
\text { Whitea }\end{array}$ & -6.71 & 10.63 & -0.06 & 0.30 & 0.46 \\
\hline Female & 6.04 & 22.49 & 0.02 & 0.04 & 0.20 \\
\hline \multicolumn{6}{|l|}{ Age } \\
\hline Young (18-20) & $41.46^{*}$ & 21.24 & 0.16 & 0.05 & 0.21 \\
\hline Old $(41+)$ & 6.48 & 22.98 & 0.02 & 0.04 & 0.20 \\
\hline Middle-aged" & & & & & \\
\hline \multicolumn{6}{|l|}{ Offense Type } \\
\hline Homicide & -11.20 & 23.19 & -0.04 & 0.05 & 0.21 \\
\hline Assault & $40.80^{* *}$ & 18.42 & 0.20 & 0.08 & 0.27 \\
\hline Burglary & -15.45 & 15.39 & -0.12 & 0.21 & 0.41 \\
\hline Theft & -4.49 & 20.48 & -0.02 & 0.08 & 0.27 \\
\hline Auto Theft & 7.82 & 33.36 & 0.02 & 0.02 & 0.14 \\
\hline Forgery & 7.77 & 29.44 & 0.04 & 0.09 & 0.28 \\
\hline Rape & 4.31 & 24.14 & 0.02 & 0.05 & 0.21 \\
\hline Narcotics & -11.43 & 26.46 & -0.06 & 0.11 & 0.31 \\
\hline Other Felony & -7.95 & 17.09 & -0.05 & 0.12 & 0.33 \\
\hline Robberya & & & & & \\
\hline Firearm Used & 7.15 & 19.67 & 0.04 & 0.08 & 0.27 \\
\hline Possession & -13.48 & 23.12 & -0.10 & 0.20 & 0.40 \\
\hline Offense Severity & 4.42 & 3.17 & 0.16 & 3.79 & 1.94 \\
\hline Offense Specialization & $25.19 * *$ & 10.97 & 0.20 & 0.24 & 0.43 \\
\hline \multicolumn{6}{|l|}{ Mode of Disposition } \\
\hline Plea & -0.98 & 21.44 & -0.01 & 0.83 & 0.38 \\
\hline Jury & 31.87 & 23.94 & 0.20 & 0.13 & 0.34 \\
\hline Judgea & & & & & \\
\hline Process Time in Days & $0.09 *$ & 0.05 & 0.15 & 149.81 & 96.27 \\
\hline (Constant) & 5.00 & 30.72 & & & \\
\hline \multicolumn{3}{|l|}{ Prison Sentence Length } & & 42.32 & 54.67 \\
\hline$N=149$ & \multicolumn{2}{|c|}{$\mathrm{F}=2.02 * * *$} & \multicolumn{2}{|c|}{$\begin{array}{l}\mathbf{R}^{2}=.25 \\
\mathbf{R}^{2}=.13\end{array}$} & \\
\hline
\end{tabular}

${ }^{*}$ Sig at $\mathrm{P} \leq 10$.

**Sig at $\mathrm{P} \leq .05$.

$* * *$ Sig at $\mathrm{P} \leq .01$.

"Reference category. 
TABLE 7

Regression of Sentence Length on Exogenous Factors, Third Arrests

\begin{tabular}{|c|c|c|c|c|c|}
\hline & b & se. of $b$ & $\beta$ & $\overline{\mathbf{x}}$ & s.d. \\
\hline \multicolumn{6}{|l|}{ Race/Ethnicity } \\
\hline $\begin{array}{l}\text { Chicano } \\
\text { Black } \\
\text { Whitea }\end{array}$ & $\begin{array}{l}-15.68 \\
-16.92\end{array}$ & $\begin{array}{l}19.72 \\
12.97\end{array}$ & $\begin{array}{l}-0.08 \\
-0.13\end{array}$ & $\begin{array}{l}0.11 \\
0.41\end{array}$ & $\begin{array}{l}0.32 \\
0.49\end{array}$ \\
\hline $\begin{array}{l}\text { Female } \\
\text { Age }\end{array}$ & 1.68 & 26.80 & 0.01 & 0.06 & 0.23 \\
\hline $\begin{array}{l}\text { Young }(18-20) \\
\text { Old }(41+) \\
\text { Middle-aged"a }\end{array}$ & $\begin{array}{r}-31.75 \\
2.47\end{array}$ & $\begin{array}{l}38.49 \\
26.17\end{array}$ & $\begin{array}{r}-0.08 \\
0.01\end{array}$ & $\begin{array}{l}0.02 \\
0.07\end{array}$ & $\begin{array}{l}0.15 \\
0.25\end{array}$ \\
\hline \multicolumn{6}{|l|}{ Offense Type } \\
\hline $\begin{array}{l}\text { Homicide } \\
\text { Assault } \\
\text { Burglary } \\
\text { Theft } \\
\text { Auto Theft } \\
\text { Forgery } \\
\text { Rape } \\
\text { Narcotics } \\
\text { Other Felony } \\
\text { Robberya }\end{array}$ & $\begin{array}{r}-27.15 \\
5.00 \\
-18.39 \\
-30.67 \\
-26.43 \\
-52.65 \\
-39.98 \\
-38.04 \\
-26.66\end{array}$ & $\begin{array}{l}41.63 \\
35.21 \\
22.15 \\
27.46 \\
43.72 \\
40.39 \\
34.85 \\
29.75 \\
22.20\end{array}$ & $\begin{array}{r}-0.07 \\
0.01 \\
-0.13 \\
-0.15 \\
-0.06 \\
-0.19 \\
-0.12 \\
-0.18 \\
-0.13\end{array}$ & $\begin{array}{l}0.02 \\
0.03 \\
0.28 \\
0.11 \\
0.02 \\
0.06 \\
0.04 \\
0.11 \\
0.11\end{array}$ & $\begin{array}{l}0.15 \\
0.18 \\
0.45 \\
0.32 \\
0.15 \\
0.23 \\
0.20 \\
0.31 \\
0.32\end{array}$ \\
\hline Firearm Used & 15.61 & 30.04 & 0.05 & 0.05 & 0.22 \\
\hline Possession & 3.74 & 29.76 & 0.02 & 0.12 & 0.33 \\
\hline Offense Severity & $11.04^{*}$ & 5.36 & 0.31 & 3.60 & 1.83 \\
\hline Offense Specialization & 30.71 & 22.66 & 0.14 & 0.17 & 0.29 \\
\hline \multicolumn{6}{|l|}{ Mode of Disposition } \\
\hline $\begin{array}{l}\text { Plea } \\
\text { Jury } \\
\text { Judge: }\end{array}$ & $\begin{array}{l}20.36 \\
27.88\end{array}$ & $\begin{array}{l}27.54 \\
30.65\end{array}$ & $\begin{array}{l}0.13 \\
0.16\end{array}$ & $\begin{array}{l}0.79 \\
0.15\end{array}$ & $\begin{array}{l}0.41 \\
0.36\end{array}$ \\
\hline $\begin{array}{l}\text { Process Time in Days } \\
\text { (Constant) }\end{array}$ & $\begin{array}{r}-0.00 \\
13.58\end{array}$ & $\begin{array}{r}0.06 \\
41.48\end{array}$ & -0.01 & 153.59 & 114.16 \\
\hline $\begin{array}{l}\text { Prison Sentence Length } \\
\qquad N=124\end{array}$ & $F=$ & & adj & $\begin{array}{l}49.12 \\
.21 \\
.05\end{array}$ & 64.38 \\
\hline
\end{tabular}

*Sig at $\mathrm{P} \leq .05$.

"Reference category.

For fourth and later arrests, the use of firearms in committing an offense significantly increases the sentence length. Table 8 shows that for fourth arrests, firearms use increases the sentence length by fourteen months. This effect is significant, though not at the level generally desired for social science research. Rather, it is signficant at the 10 level, meaning that ten times out of 100 this same effect will result from chance factors alone. 
TABLE 8

Regression of Sentence Length on Exogenous Factors, Fourth ArREsts

\begin{tabular}{|c|c|c|c|c|c|}
\hline & $\mathbf{b}$ & se. of $b$ & $\beta$ & $\overline{\mathbf{x}}$ & s.d. \\
\hline \multicolumn{6}{|l|}{ Race/Ethnicity } \\
\hline Chicano & 4.95 & 6.02 & 0.09 & 0.18 & 0.39 \\
\hline $\begin{array}{l}\text { Black } \\
\text { Whitea }\end{array}$ & -5.74 & 4.68 & -0.13 & 0.39 & 0.49 \\
\hline $\begin{array}{l}\text { Female } \\
\text { Age }\end{array}$ & -5.50 & 14.22 & -0.04 & 0.02 & 0.14 \\
\hline $\begin{array}{l}\text { Young }(18-20) \\
\text { Old }(41+) \\
\text { Midddle-aged }^{\mathbf{a}}\end{array}$ & $\begin{array}{r}1.35 \\
-5.94\end{array}$ & $\begin{array}{r}13.69 \\
9.15\end{array}$ & $\begin{array}{r}0.01 \\
-0.06\end{array}$ & $\begin{array}{l}0.02 \\
0.05\end{array}$ & $\begin{array}{l}0.14 \\
0.22\end{array}$ \\
\hline \multicolumn{6}{|l|}{ Offense Type } \\
\hline $\begin{array}{l}\text { Homicide } \\
\text { Assault } \\
\text { Burglary } \\
\text { Theft } \\
\text { Auto Theft } \\
\text { Forgery } \\
\text { Rape } \\
\text { Narcotics } \\
\text { Other Felony } \\
\text { Robberya }\end{array}$ & $\begin{array}{r}-5.28 \\
-11.17 \\
-8.45 \\
-10.29 \\
0.11 \\
-11.45 \\
-16.68 \\
-8.40 \\
-10.27\end{array}$ & $\begin{array}{r}20.37 \\
8.34 \\
8.01 \\
9.87 \\
9.83 \\
13.95 \\
19.38 \\
15.09 \\
9.92\end{array}$ & $\begin{array}{r}-0.03 \\
-0.16 \\
-0.18 \\
-0.14 \\
0.00 \\
-0.12 \\
-0.08 \\
-0.11 \\
-0.16\end{array}$ & $\begin{array}{l}0.01 \\
0.10 \\
0.26 \\
0.08 \\
0.11 \\
0.05 \\
0.01 \\
0.08 \\
0.13\end{array}$ & $\begin{array}{l}0.10 \\
0.29 \\
0.44 \\
0.28 \\
0.31 \\
0.22 \\
0.10 \\
0.28 \\
0.33\end{array}$ \\
\hline Firearm Used & $14.02^{*}$ & 7.54 & 0.23 & 0.14 & 0.35 \\
\hline Possession & 0.13 & 10.72 & 0.00 & 0.20 & 0.40 \\
\hline Offense Severity & $5.27 * *$ & 1.63 & 0.44 & 3.04 & 1.77 \\
\hline Offense Specialization & 8.05 & 9.06 & 0.09 & 0.16 & 0.23 \\
\hline \multicolumn{6}{|l|}{ Mode of Disposition } \\
\hline $\begin{array}{l}\text { Plea } \\
\text { Jury } \\
\text { Judgea }\end{array}$ & $\begin{array}{r}7.57 \\
1.25\end{array}$ & $\begin{array}{l}13.90 \\
14.54\end{array}$ & $\begin{array}{r}-0.12 \\
0.02\end{array}$ & $\begin{array}{l}0.86 \\
0.12\end{array}$ & $\begin{array}{l}0.35 \\
0.32\end{array}$ \\
\hline Process Time in Days & 0.02 & 0.02 & 0.11 & 132.72 & 95.48 \\
\hline (Constant) & 28.37 & 17.55 & & & \\
\hline Prison Sentence Length & & & & 35.79 & 21.08 \\
\hline $\mathrm{N}=95$ & \multicolumn{2}{|c|}{$F=2.69 * * *$} & \multicolumn{2}{|c|}{$\begin{array}{r}R^{2}=.44 \\
\text { adj } R^{2}=.27\end{array}$} & \\
\hline
\end{tabular}

* Sig at $\mathrm{P} \leq .10$.

$* *$ Sig at $\mathrm{P} \leq .01$.

$* *$ Sig at $\mathrm{P} \leq .001$.

"Reference category.

For fifth or later arrests, Table 9 shows that firearms use increases the sentence length by twenty-nine months, and this effect is significant at the desired .05 level. Thus, the mandated sentence enhancer for firearms offenses is used, but only when the defendant has been arrested at least four times in the three-year period analyzed here. It should be noted that the earlier arrests may or may not have involved firearms. 


\section{TABLE 9}

Regression of Sentence Length on Exogenous Factors, FifTh or LATER ARrests

\begin{tabular}{|c|c|c|c|c|c|}
\hline & b & se. of $b$ & $\boldsymbol{\beta}$ & $\overline{\mathbf{x}}$ & s.d. \\
\hline \multicolumn{6}{|l|}{ Race/Ethnicity } \\
\hline Chicano & 6.92 & 7.47 & 0.12 & 0.15 & 0. \\
\hline $\begin{array}{l}\text { Black } \\
\text { White }\end{array}$ & 2.92 & 5.43 & 0.07 & 0.53 & 0.50 \\
\hline \multicolumn{6}{|l|}{$\begin{array}{l}\text { Female } \\
\text { Age }\end{array}$} \\
\hline Young (18-20) & 3.89 & 10.08 & 0.04 & 0.05 & 0.21 \\
\hline Old $(41+)$ & 6.23 & 12.24 & 0.07 & 0.06 & 0.24 \\
\hline Middle-ageda & & & & & \\
\hline \multicolumn{6}{|l|}{ Offense Type } \\
\hline Homicide & - & - & - & 0 & 0 \\
\hline Assault & 10.67 & 14.04 & 0.09 & 0.03 & 0.1 \\
\hline Burglary & 7.62 & 10.38 & 0.17 & 0.27 & 0.45 \\
\hline Theft & 5.37 & 11.27 & 0.10 & 0.15 & 0.36 \\
\hline Auto Theft & 5.15 & 13.94 & 0.06 & 0.06 & 0.24 \\
\hline Forgery & 8.83 & 13.73 & 0.12 & 0.08 & 0.27 \\
\hline Rape & $35.64 *$ & 14.70 & 0.30 & 0.03 & 0.17 \\
\hline Narcotics & 4.85 & 11.07 & 0.08 & 0.12 & 0.33 \\
\hline $\begin{array}{l}\text { Other Felony } \\
\text { Robberya }\end{array}$ & -2.53 & 9.84 & -0.05 & 0.17 & 0.38 \\
\hline Firearm Used & $29.01^{*}$ & 13.31 & 0.30 & 0.05 & 0.21 \\
\hline Possession & -6.79 & 9.38 & -0.12 & 0.17 & 0.38 \\
\hline Offense Severity & $6.46^{*}$ & 2.53 & 0.49 & 3.15 & 1.55 \\
\hline Offense Specialization & -6.49 & 11.01 & -0.06 & 0.15 & 0.20 \\
\hline \multicolumn{6}{|l|}{ Mode of Disposition } \\
\hline Plea & -12.38 & 11.52 & -0.24 & 0.82 & \\
\hline $\begin{array}{l}\text { Jury } \\
\text { Judgea }\end{array}$ & -6.38 & 12.93 & -0.11 & 0.14 & 0. \\
\hline Process Time in Days & -0.04 & 0.03 & -0.16 & 114.33 & 84.00 \\
\hline (Constant) & 15.73 & 16.87 & & & \\
\hline Prison Sentence Length & \multirow{2}{*}{\multicolumn{2}{|c|}{$F=3.18^{* *}$}} & & 28.39 & 20.4 \\
\hline$N=66$ & & & adj & $\begin{array}{l}.57 \\
.39\end{array}$ & \\
\hline
\end{tabular}

*Sig at $\mathrm{P} \leq .05$.

$* *$ Sig at $P \leq .001$.

aReference category.

In addition to and controlling for the firearms effect, the severity of the crime also significantly increases the prison sentence for fourth and later arrests. For fifth or later arrests, persons convicted of rape receive longer sentences than similar defendants convicted of robbery. ${ }^{39}$

39. In California using a firearm during a rape carries a three-year mandatory sentence in addition to the rape sentence. Cal. Penal. Code $\$ 12022.5$ (West Supp. 1984). Apparently, for fifth and later offenses, rapists who use a gun are assigned longer sentences, but for fourth or carlicr offenses, the enhancement law is not applied. 
Interestingly, the coefficients for crime severity in Table 8 and Table 9 are smaller than those for firearms. This result means that for earlier arrests it is the severity of the offense (along with the type of offense) that has the greatest influence on sentence length. For fourth arrests, the coefficient for firearms attains the minimally acceptable level of significance, indicating an increase of fourteen months to the base sentence for those defendants using firearms. In contrast, each one-unit increase in the nine-point severity scale results in an additional five months of prison. For fifth or later arrests, use of a firearm in committing the offense increases the sentence length by two and one-half years (twenty-nine months), while each increase in the severity scale increases the sentence by only six months.

Another way of looking at these significant effects is to compare the standardized coefficients. These coefficients, called beta weights, indicate which variables account for the greatest proportion of the variance in sentence length within a given sample. Since the severity and firearms variables are measured differently (i.e., severity is an integer scale and firearms is dummycoded), the effects in standard deviational units provided by the beta weights are informative. For fourth arrests, the betas reported in Table 8 show that severity accounts for a larger proportion of the variation in sentence length than does firearms use (beta weights are .44 and .23 , respectively). For fifth or later arrests, Table 9 shows that severity again accounts for a larger proportion of the variance than firearms (betas of .49 and .30 , respectively). Thus, offense severity consistently explains the greatest amount of variation in sentence length, even though for fourth or later arrests each additional point on the severity scale adds less time to the sentence than does the difference between using a gun and not using a gun.

\section{$\mathrm{V}$ \\ Conclusion}

Like the Michigan gun law, the California sentence enhancer is not used by the courts. Moreover, speculation that a longer observation period might show the law to be effective ${ }^{40}$ is not borne out by data covering a three-year period. Only the most serious repeat offenders are given additional sentences for committing crimes with guns. The law is probably used as a mechanism for "throwing the book" at these defendants.

The reason why the enhancement laws are not used is unclear. Perhaps judges resent mandatory sentencing as an infringement on their discretion, especially if they view rapes and homicides committed with knives and blunt instruments as messier and more heinous than such crimes committed with firearms. Another possibility is that defendants who used firearms may plead guilty especially quickly, ${ }^{4}$ and a quick plea reduces severity of the sentence. Additionally, the firearm charge may be used as a bargaining chip in a plea

40. See Loftin \& McDowall, supra note 4, at 163.

41. See Zatz \& Lizotte. The Timing of Court Processing: Toumards Linking Theory and .1/ethod, 23 Criminology 313, 325 (1985). 
bargain agreement. It is also possible that judges do not realize the crimereducing potential of such laws. Alternatively, judges may reason that given a hopelessly overcrowded prison system, mandatory prison sentences are impossible to administer. If this were true, it would imply that judges do not understand the life-saving and crime-reducing benefits of incarcerating gun criminals as opposed to nongun criminals.

Another explanation is suggested by Joan Petersilia's findings across three states that whites show a clear preference for the use of guns in crime, Hispanics for knives, and blacks also for guns (but not to the same extent as whites). ${ }^{42}$ Although the current study did not find any major effects of race/ethnicity, perhaps judges are less likely to lock up whites using guns than blacks or Hispanics using knives for the same offenses. Of course, if this is true it implies discrimination in sentencing.

Mandatory sentence enhancers for the use of firearms during felonies may reduce deaths in the commission of crime, and they may reduce the overall crime rate due to special or general deterrence. They certainly reduce the death and crime rates through incapacitation. They could assist in the elimination of gender, class, race, or ethnic discrimination in sentencing. These laws could also make citizens feel more secure by fostering a sense of trust in the ability of the criminal justice system effectively to mete out reasonable punishments. Beyond this speculation, however, it is impossible for social scientists to give public policy advice on the efficacy of these laws so long as the laws are not enforced. If the laws were enforced, their effect on the crime rate or on the death rate due to crime could be evaluated. Changes in discrimination in sentencing could also be evaluated. Finally, the effect on public attitudes toward the criminal justice system could be measured. All of this research could lead to sound public policy advice-but it cannot be offered until the mandatory sentence enhancer laws are enforced.

42. J. Petersilita, supra note 32 , at viii, xxi, 78-79. 
. 